\title{
A MINI REVIEW ON ANTIDIABETIC PLANT DERIVED ALKALOIDS RAJANI SINGH ${ }^{1}$
}

\author{
Department of Chemistry, T.D.P.G. College, Jaunpur, Uttar Pradesh, India
}

\begin{abstract}
Diabetes is a enocrine and metabolic disease in which blood sugar level becomes very high. The inadequacy of insulin or dysfunction of insulin or both result disturbances in the metabolism of fat, carbohydrate and protein. The chronic hyperglycemea (diabetes) damage the body system. Body does not properly process blood glucose to be used as energy. The control and management of diabetes with synthetic drugs is costly. The synthetic drugs are toxic and chances of side effects are very much high. Therefore a safer and effective treatment is needed with lower cost and lesser side effects. The plant derived chemicals play very important role in the management of diabetes mellitus. The natural alkaloids have been reported to exert a wide range of anti-diabetic activities. In present review article, an attempt has been made to report the various alkaloids isolated from plants with their antidiabetic activities.
\end{abstract}

KEYWORDS: Diabetes Mellitus, Insulin, Photochemical, Alkaloids

Diabetes is one of the most common health problems. Diabetes is a very much dangerous to human being like cancer and cardiovascular diseases. The insulin secreted from pancreas, control sugar level. Insulin transport glucose to our body cells from blood stream. The absence or inadequate production of insulin or inability of body to use insulin properly causes diabetes. If diabetes is not controlled, our body organs mainly eyes, kidney, heart, nerves and blood vessels may be damaged. Diabetes mellitus is broadly divided into type-1 and type2 diabetes. In type- 1 diabetes the immune system causes destruction of pancreatic beta-cells and body becomes unable to produce insulin. In type- 2 diabetes either body does not produce enough insulin or insulin is not used properly by body. Thus there is insulin resistance. Hence in both type of diabetes glucose level in blood becomes high.

Since the start of the human civilization, we are using plants as the important source of medicines. The phytochemicals are used now a day as drugs of interest because of the lesser side effects, low cost of treatment and their effectiveness. The plant derived chemicals have been reported to play an important role in the control and management of diabetes millitus (Aniszews, 2015). Alkaloids isolated from several medicinal plants, have been found to possess a wide range of antidiabetic properties (Sharma et al., 2010) (Rajan et al., 2018) (Gidad et al., 2008) (Soon et al., 2013) (Aska and Pindiga, 2010). Alkaloids present in plants play the role of chemical defense. The nitrogen is in a negative oxidation state in alkaloids which are cyclic compounds. Cardell et al., 2001, have reported the role of many plant derived alkaloids to control diabetes. Berberine has been found to promote insulin secretion in rat's pancreatic islets (Wang et al., 2008). The following four classes of alkaloids have been found to show anti-diabetic activity: (i) Indole alkaloids (ii) Isoquinoline alkaloids (iii) Aminoalkaloids (iv) Terpenoidal alkaloids. It is also well known that some of the alkaloids are biosynthesized in plants from precursors. Indole, piperdine, pyrrolidine, phenyl ethyl amine and imidazole alkaloids are derived from tryptophan, lysine, ornithine, tyrosine and histidine respectively.

A number of indole alkaloids, isolated from catheranthus roseus, were reported to increase metabolism of glucose and beta-cell rejuvenation and regeneration. Vindogentianine shows hypoglycemic activity (Tiong et al., 2015). Isoquinolene alkaloids palmatine sulphate, palmatine chloride and berberine isolated from Coptis Japonica were found as aldose reductase inhibitor (Lee, 2002). 8-Oxoberberine isolated from Berberis brevissima has inhibited protein, tyrosine phosphatase T13 (Ali et al., 2013). Nonterpenoidal alkaloids from the seeds of Nigella glandulifera Fryen have been reported to show inhibition activity of protein of tyrosine phosphatase 1B (PTP1B) in vitro (Tang et al., 2017). Mycaminose has been characterized to reduce blood sugar level (Kumar et al., 2008). Aegeline an alkaloidal-amide isolated from bark of aegle marmolos (Linn) corr, serr, was found to have antihyperglycemic activity in STZ induced rats (Gandhi, 2012). Piperine, pipernonaline and dehydropipernonaline isolated from piper retrafraction fruits, were reported as potential antidiabetic agents (Sharma et al., 2018). Trigolelline isolated from Fenugreek, was reported to increase the sensitivity of tissues to insulin action by increasing the activity of enzymes of glucose utilization (Yoshinario and Igarashi, 2014). The pyrrolidine alkaloids Radicamins A and Radicamins B isolated from L. Chinensis were

${ }^{1}$ Corresponding author 
reported as $\alpha$-glucosidase inhibitor (Shibano et al., 2001). The carbazole alkaloids isolated from Murraya koenigil were reported as potent antidiabetic agents. The 4-Koenidine was reported to control diabetes and manage insulin resistance (Om Patel et al., 2016).

The recent advancements in antidiabetic alkaloids isolated from various plants, is summarized here in this brief review.

\section{PLANT DERIVED ALKALOIDS ANTIDIABETIC AGENTS}

AS

Some important alkaloids isolated from plants with their antidiabetic properties are given in the following lines:

1. Aegeline, Marmesin and Marmelosin (Aegle Marmelos): Regeneration of pancreatic $\beta$-cells and increases insulin secretion (Kamalkkanan and Prince, 2005)

2. Berberine (Tinospora cordefollia Iberberisaristata): Activity of hexokinase and phosphofructokinase is enhanced resulting in glucose transport, carbohydrate digestion and absorption, DDP-IV inhibition (Singh et al., 2003) (Al Masri et al., 2009)

3. Betaine, Achyranthine, $\beta$-ecdysone (Achyranthus aspera): Carbohydrate digestion and absorption is affected (Akhtar and Iqbal, 1991)

4. Boldine and isoboldine (Peumus boldus): Prevent hyperglycemea in diabetic rats, renal alternations (Romina et al., 2013)

5. Cantharanthine, Vindoline, Vindolinine, Vindoblastine and Vincristine (Cantharanthus roseus, Vinca roseus): Free radicals scavenging action, Reduction in blood sugar level (Jarald et al., 2008) (Chattopadhyay, 1999)

6. Castanospermine, australine (Caslanospermium australe): DPP-IV inhibition (Bharti et al., 2012)

7. Castanospermine epifagomine, Fagomine (Xanthocercis Zambesiaca): Carbohydrate digestion and absorption, Insulin secretion (Akhtar, 1992)

8. Cryptolepine (Cryptolepis sanguinolenta): Decrease in blood glucose level, increase glucose uptake in 3T3-L1 cells (Heo et al., 1998)

9. Casuarine-6-o- $\alpha$-glucoside (Syzygium malaccense): Inhibit $\alpha$-glucosidase activity (Kiyoteru et al., 2005)

10. Calystegine $B_{2}$ (Nicandra Physalodis): Reduce diet induced hyperglycemia and indogeneous insulin secretion by inhibiting intestinal R-gluclosidase (Griffiths et al., 1996)
11. Caffeine, Catechins (Camellia sinensis): Inhibit development of insulin resistance. Decreases glucose absorption from intestine (Alam, 2016) (Tedeng et al., 2010).

12. 1-Ephedrine (Ephedra distachya Linn): Suppression of hypergycemia in rats (Xiu et al., 2001)

13. Ginkgolide (Ginkobiloba): Increases insulin secretion (Pinto et al., 2009)

14. 11-Hydroxypalmatine (Steplenia glabra): Causes reduction in blood glucose (Senwal et al., 2010)

15. Harmane, norharmane (Tribulus terrestris): Stimulate insulin secretion by the activation of imidazoline I binding sites in the pancreatic- $\beta$-cell (Kirtikar and Bani, 1993)

16. $\beta$-Carboline harmane, pinoline (Tribulus terrestris): Increases insulin secretion (Cooper et al., 2003)

17. 1-Deoxynojirimycin (Morusalba) : Potent $\alpha-$ glucosidase inhibitor (Oku et al., 2006)

18. Javaberine A, Javaberine A hexa acetate, Javaberine, $B$ hexa acetate (Talinum panicalatum): Inhibitors of TNF- $\alpha$-production by macrophages and fat cells. The plant used as diet any suppliment to prevent diabetes (Shimoda et al., 2001) (Catthareeya et al., 2013)

19. Jambosine (Syzgium Cumini): It checks the conservation of starch (Murlimanohar, 2011)

20. Jatrorrhizine, magnoflorine, palmatine (Tinospora cordifolia): Stimulated insulin secretion for RIN in 5F cell line (Patel and Mishra, 2011)

21. Lupanine, 13- $\alpha$-hydroxylupanine, 17-Oxolupanine (Lupinus perrenis): Enhance glucose stimulated insulin release and lower blood sugar level (Zopez et al., 2004)

22. Lepidine and Semilepidine (Lepidinum sativum): Potentiate pancreatic secretion of insulin from islet $\beta$-cells (Shukla et al., 2012)

23. Mahanimbine (Murray Koenigii): Lower blood glucose level (Kumar et al., 2010)

24. Nuceferine (Nelumbo nucefera): Stimulate insulin secretion (Nguyen et al., 2012)

25. Pangomol, Karangin (Pongomia pinnala): Shows excess level of insulin circulating in blood (Tamarkar et al., 2008) (Hyper insulinimic activity)

26. Piperumbellactum A (Piperumbellactum): Inhibition of glucosidase enzyme (Tabopda et al., 2008)

27. Schilzeines A, B and C (Penures Schulzes): Inhibit $\alpha$-glucosidase activity (Takada et al., 2004)

28. Swerchirin (Swertia chirayita): In fasted, Fed and glucose loaded albino rats, the blood glucose level lowering effect observed (Bajpai et al., 1991) 
29. Sotolon, Trigonelline, gentianine (Trigonellia foenum graecum): The activity of fructose-1, 6biphosphatase is suppressed and its dephosphorylation checked (Khosla et al., 1995)

30. Tecomine (Tecomastans): Glucose uptake rate increased (Costantino et al., 2003)

31. Tetrandrine $2{ }^{\prime}-\mathrm{N}-\beta$-Oxide: Fangchinoline, $2{ }^{\prime}-\mathrm{N}-$ methyl tetrandrium chloride (Stephamia tetrendra). Reduce high blood glucose level and increase blood insulin (Tsutami et al., 2003)

\section{CONCLUSION}

The prevention and management of diabetes is still a major challenge to researchers. Hence the scientists, medical practisnors and herbalogists must try to investigate the various ways to manage and control the diabetes. Thus new class of drugs must be searched to overcome the diabetic problems. The plant derived antidiabetic alkaloids have been reported less costly, less toxic with lesser side effects. There is increasing demand to search and develop new herbal formulations and plant based antidiabetic alkaloids with their mechanism of action to diabetic problems. The control of diabetes with phytochemicals must be preferred over conventional synthetic drugs. This review justify the applications of plant alkaloids and also provide a platform for further investigations to explore the antidiabetic potentials of the plants.

\section{REFERENCES}

Akhtar M.S. and Iqbal J., 1991. Hypoglycemic activities of some Achyranthes aspera in normal and alloxan-diabetic rabbits. J. Ethnopharmacol. 31: 49-57.

Akhtar M.S., 1992. Hypoglycemic activities of some indigenous medicinal plants tractievelly used as antidiabetic drugs. J. Pak Med. Assoc., 42: 271277.

Al Masri I.M., Mohammad M.K. and Tahaa M.D., 2009. Inhibition of DPP-IV is one of the mechanisms explaining the hypoglycemic effect of berberine. J. Enzyme Inhib. Med. Chem., 24: 1061-1066.

Alam M.A., Shubhan N. and Hussain H., 2016. Natur. Metab., 13(1).

Ali S., Lgoli J. and Clements C., 2013. Antidiabetic and antimicrobial activities of fractions and compounds isolated from Berberis brevissima
Jafriad Berberis Parkeriana schneid, Bangladesh Journal of pharmacology, 8(3): 336-342.

Aniszews K., 2015. Alkaloids: Chemistry, biology, ecology and applications. $2^{\text {nd }}$ Ed. Amastardam : Elsivier, 1-475.

Aska A.S. and Pindiga Y.N., 2010. Antidiabetic effects of extract of Holarrhena floribunda in rats. Medicinal and aromatic plants sciences and Biotechnology, 4(11): 52-54.

Bajpai M.B., Asthana R.K., Sharma N.K., Chaterjee S.K. and Mukherjee S.K., 1991. Hypoglycemic effect of swerchirin from the hexane fraction swertia chirayeta. Plant Med., 57: 102-04.

Bharti S.K., Krishnan S. and Kumar A., 2012. Antihyperglycemic activities with DPP-IV inhibition of alkaloids from seed extract of Castanospermum australe: Investigation by experimental validation of molecular dacking. Phytomedicine, 20: 24-31.

Cardell G.A., Quinn-Beattie M.L. and Farnsworth N.R., 2001. The potential of alkaloids in drug discovgery. Phytother Res., 15:183-205.

Catthareeya T., Papirom P., Chanlum S. and Kapittayanant S., 2013. Talinum paniculatum gertn: a medicinal plant with potential estrogenic activity in ovariectomized rats. Int. J. Pharm. Sci., 5(2): 478-485.

Chattopadhyay R.R., 1999. A comparative evaluation of some blood sugar lowering agents of plant origin. J. Etanopharmacol, 67(3): 367-77.

Cooper E.J., Hudson A.L., Parker C.A. and Morgan A.G., 2003. Effect of the $\beta$-carbolines harmane and pinoline one insulin. Eur. J. Pharmacol., 482: 189-96.

Costantino L., Raimondi R., Pirisino T., Brunetti P.F. and Pessotto G., 2003. Isolation and pharmacological activities of the Tecoma stans alkaloids. Farmaco, 58: 781-85.

Gandhi G.R., Ignacimuthus and Pankaj M.G., 2012. Hypoglycemic and $\beta$-cell regenerative effect of Aegle mametos (L) Corr. bark extract streptozotocin induced rats, Food Chem. Taxicol., 50: 1667-1674.

Gidad A., Ameh D.A., Atavodi S.E. and Ibrahim S., 2008. Hypoglycemic activity of naucle catefolia 
Sm. in experimental elements. Afr J. Trad Compl Alt. Med., 5(2): 201-208.

Griffiths R.C., Watson A.A., Kizu H., Asano N., Sharp H.J., Jones H.G., Wormald M.R., Fleet J.W.J. and Nash R.J., 1996. The isolation from Nicandra physalodes and identification of tee 3o-(d-glucopyranoside of 1a, 2b, 3a, 6atetrahydroxy-nor-tropane (calystegin B2). Tetrahedran Lett., 37: 3207-3208.

Heo J., Fort D.M., Carlson T.J., Noamesi B.K., NiiAmon-Kotei D. and Kenj S.R., 1998. Diabet Med., 15: 367-74.

Jarald E.E., Sheeja E. and Matwani S., 2008. Comparative evaluation of antihyperglycemic activity of various part of Catharanthus roseus Linn., Res. J. Med. Plant, 2: 10-15.

Kamalkkanan N. and Prince P.S.M., 2005. The effect of Aegle mametos fruit extraction streptozotocin diabetes, a histopathological study. J. Herb Pharmacol., 5: 87-96.

Khosla P., Gupta D.D. and Nagpal R.K., 1995. Effect of trigonella Foenum graceum (Fenugreek) on serum lipids in normal diabetic rats. Indian $\mathrm{J}$. Physiol Pharmacol., 27: 89-83.

Kirtikar K.R. and Bani B.D., 1993. Indian Medicinal Plants, Vol. 1-4, periodical Experts: Delhi.

Kiyoteru T., Shinichi T., Junchi K., Shunivhi Y., Kazuo L., Kinzo W., Sami Soni J., Taraiasi V. and Bill A., 2005. Jpn Kokas Yokkyo Koho, 12.

Kumar A., Ilavarasan R., Jayachandran M., Dzecaraman M., Arvindan D. and Padmanabham N., 2008. Antidiabetic activity of syzygium cumuni and its isolated compounds against streptozotocin induced diabetic rats, J. Med. Plants Res., 2: 246-249.

Kumar B.D., Mitra A. and Mahadevappa M., 2010. Antidiabetic of hypolipidemic effects of Mahanimbine (Carbazole alkaloid) from Murraya-Koeniggi leaves. Int. J. Phytomed., 2: 22-30.

Lee H.S., 2002. Rat lens allose reductase inhibitory activities of coptis taponica root derived quindine alkaloid, J. Agri. Food Chem., 50: 7013-16.
Murlimanohar A., 2011. For all V and S Publishers Hyderabad.

Nguyen K.H., Ta T.N., Pham T.H., Ngyun Q.T., Pham H.D. and Mishra S., 2012. Nuciferine stimulates insulin secretion from $\beta$-cell an vitro comparison with glibenclamide. J. Ethnopharmacol, 142(2): 488-95.

Oku T., Yamada M., Nakamura M., Sadamori M.N. and Nakamura N., 2006. Inhibitory effects of extractive from leaves of Morus alb on human and rat small intestine disaccharidase activity. $\mathrm{J}$. Nutr., 95: 933-932.

Om Patel P.S., Mishra A., Maurya R. and Sainy D., 2016. Natural occurring carbazole alkaloids from Murraya koenigii as potential antidiabetic agents, DOI: 10.1021/ACS Jn at Prod. 5b00883.

Patel M.B. and Mishra S., 2011. Hypoglycemic activity of alkaloidal fraction of Tinospora cordifolia. Phytomedicine, 18(12): 1045-1052.

Pinto M.D.S., Kwon Y.I. and Apostolidis E., 2009. Potential of Ginkgobiloba L. leaves in management of hyperglycemia and hypertension using in vitro models. Bioresour Technol., 100: 6594-6609.

Rajan S., Satish S. and Shankar K., 2018. Aegeline inspired synthesis of novel $\beta^{3}$-AR Agonist improves insulin sensitivity in vitro and vivo models of insulin resistance. Metabolism, 18: 113.

Romina H.-S., Alyandra Z.V., Marlene N., Artsmendi, Mauricio P.B., Jaun C.S. and Victoria V., 2013. Boldine prevents renal alteration in diabetic rats. Journal of diabetic research. Article ID 593672, 12.

Senwal D.K., Rawat U., Senwal R., Singh R. and Singh G.H., 2010. Anti hyperglycemic effect of 11hydroxypalmaline and palmatine derivative panstaphanis slabratubers. J. Asian Nat. Prod. Res., 12: 99-105.

Sharma B., Mittal A. and Dabur R., 2018. Antidiabetic agents from medicinal plants, Chem. Biol. Lett., 5(2): 63-99.

Sharma B., Salunke R. and Balomajumdar C., 2010. Antidiabetic potential of alkaloid rich fraction from Capporis decidua on diabetic mice. J. Ethanopharmacol, 127: 457-462. 
Shibano M., Tsukamoto D., Masuda A., Tanaka Y. and Kusano G., 2001. Two new pyroolidine akaloids Radicamines $\mathrm{A}$ and $\mathrm{B}$ as inhibitors of $\alpha$ glucosidase from lobelia chinesis. Lour. Chem. Pharm. Bull., 49(10): 1362.

Shimoda H., Nishida N., Ninomiyak, Matsuda H. and Yoshikawa M., 2001. Javaberine A., new TNF- $\alpha$ and nitric oxide production inhibitor from the roots of Talinum paniculatum. Heterocycles, 15(11): 2043-2050.

Shukla P., Bigoniya and Srivastava B., 2012. Hypoglycemic activity of Lepidium sativum Linn. seed total alkaloids on alloxan induced diabetic rats. Res. J. Med. Plant, 6(8): 587-596.

Singh S.S., Pandey S.C. and Srivastava S., 2003. Chemistry and medicinal properties of Tinospora cordifolia (Guduchi). Indian J. Pharmacol., 35: 83-91.

Soon H.T., Chung Y.L., Hazrina H., Aditya A. and Mohammad J.P., 2013. Antidiabetic and antioxidant properties of alkaloids from catheranthus roseus (L). G. Don Molecules, 18(8): 9770-84.

Tabopda T.K., Ngoupayo J., Liu J., Mitaine-offer A.C., Tinali Dubois M.A. and Luu B., 2008. Bioactive aristolactums from piperumbellatum. Phytochemistry, 69: 1726-1731.

Takada K., Uehara T., Nakao Y., Matunaga S., Van Soest W.M., Fusetani N. and Schulzeines A.C., 2004. New $\alpha$-glucosidase inhibitor from the marine sponge penares schulzei. J. Am. Chem. Soc., 126: 187.

Tamarkar A.K., Yadav P.P., Tiwari P., Maurya R. and Srivastava A.K., 2008. Identification of pongamal and karanjin as lead compounds with antihypergylmic activity from Pongamia pinnata fruits. J. Ethnopharmacol., 118: 435-9.
Tang D., Chen Q.B. and Xin X.L., 2017. Antidiabetic effect of three new horditerpenoid alkaloids in vitro and potential mechanism via $\mathrm{P}_{13} \mathrm{~K} / \mathrm{AkY} \mathrm{J}$. Biomedicine and Pharmacotherapy, 87:145-152.

Tedeng L., Madiraju P. and Meritaneau L.C., 2010. Mal. Nutr. Food Res., 54(2): 1753-62.

Tiong S.H., Looi C.Y. and Arya A., 2015. Vindogentianine, a hypoglycemic alkaloid from Catharanthus roseus (L). G. Don (Apocynaceac) J. Fitoterapia, 102: 182-188.

Tsutsami T., Kobayashi S., Liu Y.Y. and Kantani H., 2003. Antihyperglycemic effect of fangchinoline isolated from staphenia tetrandra radix in strertozotocin diabetic mice. Biol. Pharm. Bull., 26: 313-17.

Wang J.Q., Elu F., Leng S.H., Fang X.S., Chem, G. and Wang J.S., 2008. Facilitating effect of berberine on rat pancreatic islets through modulatory hepatic nuclear factor $4 \alpha$ expression and glycokinase activity, World J. Gastroenterol., 14(39): 6004-11.

Xiu L.M., Miura A.B., Yamanoto K., Kobayashi T., Song Q.H. and Kitamura H., 2001. Pancreatic islet regineration of ephedrine in mice with STZinduced diabetes. Am. J. Chinese Med., 29: 493500.

Yoshinari O. and Igarashi K., 2014. Antidiabetic effect of triazonelline comparison with nicotinic acid in coffee in health disease. Prevention, pp. 765775 .

Zopez P.M., Mora P.G., Wysocka W., Maiztegui B., Alzo Garaya M.E. and Zota H.D., 2004. Quinolizidine alkaloid isolated from Lupinas species entire insulin secretion. Eur. J. Phamacol., 504: 139142. 